\title{
LiDAR-Based Classification of Sagebrush Community Types
}

\author{
Temuulen Tsagaan Sankey ${ }^{1}$ and Pamela Bond ${ }^{2}$ \\ Authors are ${ }^{1}$ Research Assistant Professor, and ${ }^{2}$ Graduate Research Assistant, Boise Center Aerospace Laboratory, Idaho State University, \\ 322 East Front Street, Boise, ID 83712, USA.
}

\begin{abstract}
Sagebrush (Artemisia spp.) communities constitute the largest temperate semidesert in North America and provide important rangelands for livestock and habitat for wildlife. Remote sensing methods might provide an efficient method to monitor sagebrush communities. This study used airborne LiDAR and field data to measure vegetation heights in five different community types at the Reynolds Creek Experimental Watershed, southwestern Idaho: herbaceous-dominated, low sagebrush (Artemisia arbuscula) -dominated, big sagebrush (Artemisia tridentata spp.) -dominated, bitterbrush (Purshia tridentata) -dominated, and other vegetation community types. The objectives were 1) to quantify the correlation between field-measured and airborne LiDARderived shrub heights, and 2) to determine if airborne LiDAR-derived mean vegetation heights can be used to classify the five community types. The dominant vegetation type and vegetation heights were measured in $3 \times 3 \mathrm{~m}$ field plots. The LiDAR point cloud data were converted into a raster format to generate a maximum vegetation height map in 3-m raster cells. The regression relationship between field-based and airborne LiDAR-derived shrub heights was significant $\left(R^{2}=0.77 ; P\right.$ value $\left.<0.001\right)$. An analysis of variance test with all pairwise post hoc comparisons indicated that LiDAR-derived vegetation heights were significantly different among all vegetation community types (all $P$ values $<0.01$ ), except for herbaceous-dominated communities compared to low sagebrush-dominated communities. Although LiDAR measurements consistently underestimated vegetation heights in all community types, shrub heights at some locations were overestimated due to adjacent taller vegetation. We recommend for future studies a smaller rasterized pixel size that is consistent with the target vegetation canopy diameter.
\end{abstract}

\section{Resumen}

Las comunidades de "Sagebrush" (Artemisia spp.) constituyen el semi-desierto templado más grande en América del Norte y son pastizales muy importantes para el ganado y hábitat para la fauna silvestre. Los sensores remotos pueden proporcionar un método eficaz para monitorear las comunidades de sagebrush. Este estudio utilizó datos aéreos de LiDAR así como datos en el campo para medir la altura de la vegetación en cinco diferentes tipos de comunidades en Reynolds Creek Experimental Watershed en el Suroeste de Idaho: sagebrush bajo, herbaceo (Artemisia arbuscula) big sagebrush (Artemisia tridentata spp.) área dominanda por bitterbush (Purshia tridentata) y otro tipos de comunidades de vegetación. Los objetivos fueron: 1) cuantificar la correlación entre las medidas tomadas a nivel de campo y las medidas de los datos de LiDAR-aerea para derivar la altura de los arbustos, y 2) determinar si las medidas derivadas de las tomas aéreas de LiDAR de las alturas de la vegetación podrían usarse para clasificar los cinco tipos de comunidades. La vegetación dominante y la altura de la vegetación se midieron en parcelas de $3 \times 3 \mathrm{~m}$. Los datos de LiDAR se convirtieron en un formato para generar un mapa de la altura máxima de la vegetación en células $3 \mathrm{~m}$. La relación de la regresión entre las alturas de los arbustos derivadas de LiDAR y los datos de campo fue significativa $\left(R^{2}=0.77\right.$; valor de $\left.P<0.001\right)$. Un análisis de ANOVA con todas las comparaciones de las medias indicó que las alturas de la vegetación derivada de LiDAR fueron significativamente diferentes entre todos los tipos de las comunidades $(P<0.01)$, con la excepción de las comunidades dominadas por (Artemisia arbuscula) comparada con las comunidades dominadas por sagebrush bajo. Mientras que las mediciones de LiDAR subestimaron sistemáticamente la altura de la vegetación en todos los tipos de comunidades, las alturas de los arbustos en algunas localidades se sobreestimaron debido a la vegetación adyacente más alta. Se recomienda para futuros estudios el uso de un menor tamaño de píxel que sea consistente con el diámetro de la cubierta de vegetación bajo estudio.

Key Words: active sensors, laser data, rangeland classification, vegetation height

\section{INTRODUCTION}

Sagebrush (Artemisia spp.) communities constitute the largest temperate semidesert in North America (Anderson and Inouye

Research was funded by Grants NA050AR4601137 and NA060AR4600124 from the Nationa Oceanic and Atmospheric Administration Earth System Research Laboratory Physical Sciences Division and the Bureau of Land Management Owyhee Uplands Pilot Project (ISUBLM Agreement DLA060249).

Correspondence: Temuulen Tsagaan Sankey, Boise Center Aerospace Laboratory, Idaho State University, 322 East Front Street, Boise, ID 83712, USA. Email: sankteki@isu.edu

Manuscript received 27 January 2010; manuscript accepted 3 October 2010.
2001) and approximately 60 million hectares of rangelands in the western United States (Watts and Wambolt 1996). In the Great Basin, sagebrush communities occupy approximately $450000 \mathrm{~km}^{2}$ of the Columbia and Snake River Plateaus (Anderson and Inouye 2001). Sagebrush communities provide the dominant or co-dominant species of over 40 habitat types (Blaisdell et al. 1982; Monsen et al. 2004), where they provide food or cover necessary for over 350 wildlife species including Greater Sage Grouse (Centrocercus urophasianus; Suring et al. 2005; Tilley et al. 2006). Many sagebrush communities have been drastically altered or reduced in extent by fire regime changes, grazing practices, and invasion by nonnative plant 
species (Baker 2006). Assessment of such changes and their impacts on sagebrush communities can be costly, labor intensive, and time consuming because of the large areal extent sagebrush communities cover, and especially considering most sagebrush studies are based on field measurements. Although field-based measurements provide detailed and accurate records, they generally cover a relatively small spatial extent. Remote sensing methods might provide a more efficient method to monitor sagebrush communities across large areas (Tueller 1989; Hunt et al. 2003; Washington-Allen et al. 2006).

Previous remote sensing-based studies have used AVIRIS data (Kokaly et al. 2003) for thematic classification of sagebrush among other vegetation cover types and NOAA/ AVHRR data (Kremer and Running 1993) for classification of sagebrush communities and neighboring herbaceous communities in a sagebrush steppe. Landsat 5 Thematic mapper (TM; Knick et al. 1997) and Landsat 6 TM (Seyfried et al. 2001) images have also been used to classify various sagebrush steppe communities. Weber (2006) used Quickbird and SPOT 5 images to evaluate the separability and classification accuracy of various land-cover types in sagebrush-steppe rangelands. Furthermore, Sivanpillai et al. (2009) used a Landsat 5 TM image to predict ordinal sagebrush cover categories. Multispectral data have also been used to classify the percent cover of various sagebrush community types (Jakubauskas et al. 2001; Ramsey et al. 2004; Sankey et al. 2008b; Sivanpillai and Booth 2008). Optical remote sensing classification of rangeland vegetation is often challenging because of the sparse vegetation cover resulting in mixed reflectance from sagebrush, herbaceous vegetation, and bare ground (Okin et al. 2001).

LiDAR active remote sensing collects detailed, three-dimensional vegetation structure information. LiDAR applications, which have been most commonly used in forestry studies, are now increasingly used for rangeland vegetation classification (Weltz et al. 1994; Ritchie et al. 1995; Rango et al. 2000; Mundt et al. 2006; Streutker and Glenn 2006; Bork and Su 2007; Riano et al. 2007; Su and Bork 2007). Streutker and Glenn (2006) demonstrated a successful application of LiDAR data in classifying sagebrush presence and absence and average canopy height. They documented that accuracies in mapping sagebrush absence can be low (user's accuracy of 57\%) compared to sagebrush presence and the correlation between field-measured versus LiDAR-derived sagebrush heights can be weak. Their study focused on unburned and burned sagebrush vegetation, where average sagebrush heights were only $13 \mathrm{~cm}$ and $9 \mathrm{~cm}$, respectively. With the same methods and LiDAR processing tools, this study expands on their work to classify undisturbed sagebrush community types of varying heights in southwestern Idaho-namely, low sagebrush (Artemisia arbuscula Nutt.) -dominated, big sagebrush (Artemisia tridentata Nutt. subsp. vaseyana [Rydb.] Beetle and subsp. wyomingensis Beetle \& Young) -dominated, and bitterbrush (Purshia tridentata [Pursh] DC) -dominated community types-separately. The objectives of this study were 1) to quantify the relationship between field-measured and airborne LiDARderived shrub heights in an undisturbed sagebrush steppe, and 2) to determine if LiDAR-derived average vegetation heights can be used to classify these community types. Low sagebrush is typically a low, spreading, irregularly branched shrub that obtains a height of up to $50 \mathrm{~cm}$ (Monsen et al.
2004). Big sagebrush typically grows up to $50-100 \mathrm{~cm}$ in height (Wambolt and Frisina 2002; Monsen et al. 2004). Bitterbrush can range from $60 \mathrm{~cm}$ to $185 \mathrm{~cm}$ in height and can have a variable canopy width of up to $250 \mathrm{~cm}$ (Dyer et al. 2008). Bitterbrush often grows in an upright, tree-like form (Nord 1965; Monsen et al. 2004). Using LiDAR-derived canopy height estimates, this study aimed to determine whether differences in shrub height were statistically significant among the low sagebrush-, big sagebrush-, and bitterbrush-dominated communities. Such height difference might then be used to distinguish these communities.

\section{METHODS}

\section{Study Site Description}

The data presented here were collected at the Reynolds Creek Experimental Watershed (RCEW), which is administered by the United States Department of Agriculture, Agricultural Research Service. The RCEW was established in 1960 as one of several experimental watersheds for hydrologic and natural resources research (Slaughter et al. 2001). The watershed is $238 \mathrm{~km}^{2}$ in extent and ranges in elevation from $\sim 1000 \mathrm{~m}$ to $\sim 2000 \mathrm{~m}$. Corresponding annual precipitation ranges from $230 \mathrm{~mm} \cdot \mathrm{yr}^{-1}$ at the lower elevations to $>1100 \mathrm{~mm} \cdot \mathrm{yr}^{-1}$ at the higher elevations. Soils are derived from granitic and volcanic rocks as well as lake-bed sediments. Plant communities at lower elevations are typical of the Great Basin Desert and dominated by mixed sagebrush and herbaceous species. At higher elevations, big sagebrush, aspen (Populus tremuloides), and Douglas fir (Pseudotsuga menziesii) are common. The RCEW has not experienced widespread wild or prescribed fire since the 1930s. Detailed information on watershed geography, vegetation, soils, hydrology, and weather can be obtained from previously published references (Slaughter et al. 2001). Within the RCEW, this study focused on three specific areas (Fig. 1), where herbaceous plants and scattered trees were found along with three different shrub community types. The shrub community types were low sagebrush-dominated communities with bluebunch wheatgrass (Pseudoroegneria spicata [Pursh] A. Löve subsp. spicata) and Idaho fescue (Festuca idahoensis Elmer); big sagebrush-dominated communities with bluebunch wheatgrass; and bitterbrush-dominated communities with big sagebrush and bluebunch wheatgrass. The herbaceous-dominated communities included small areas dominated by bluebunch wheatgrass or Idaho fescue with no shrubs present. The areas with scattered western juniper trees (Juniperus occidentalis Hook) or tall willows (Salix lutea Nutt and Salix lucida subsp. caudate [Nutt] E. Murr) were classified as other vegetation.

\section{Image Analysis}

The airborne LiDAR data were acquired in November 2007 through Watershed Sciences Inc., with the use of a Leica ALS50 Phase II laser mounted on a Cessna Caravan 208B fixed-wing aircraft flying at a 900-m height and 105-knot speed with 50\% flight-line overlap. The study sites spanned across 15 postprocessed LiDAR data tiles, which included a total of 38 original flight lines. The Leica ALS50 Phase II is a discrete return system that measures up to four laser returns per pulse. 


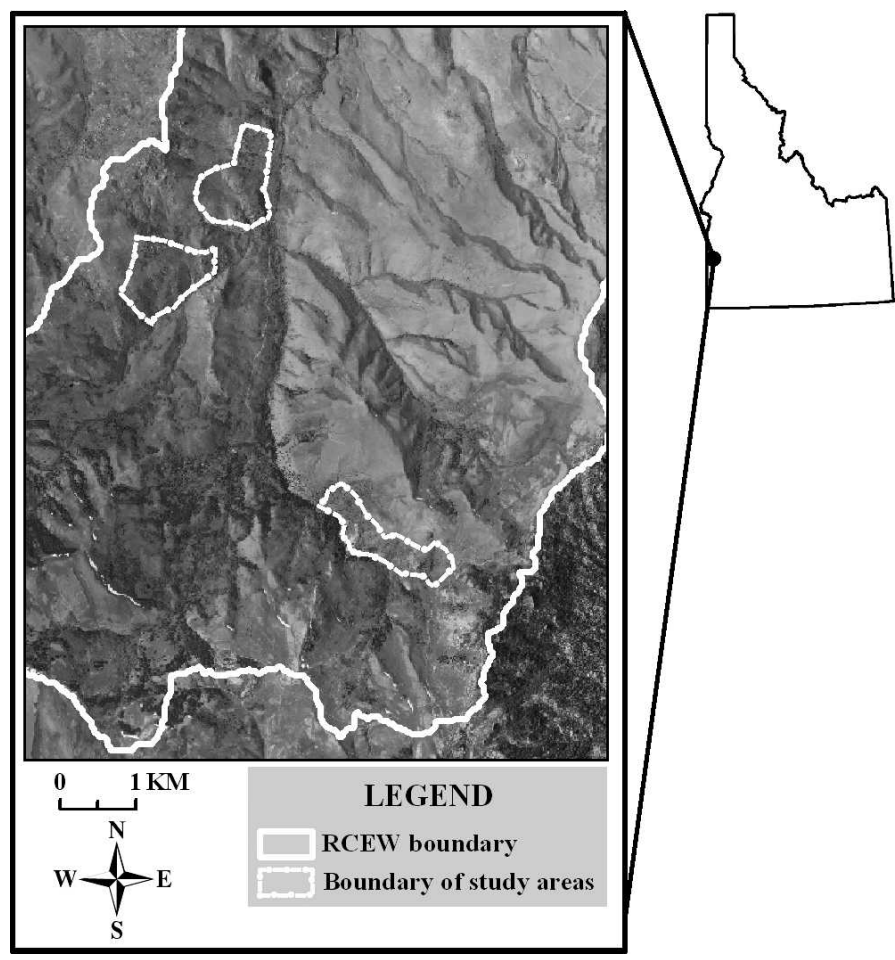

Figure 1. Map of the study areas in the Reynolds Creek Experimental Watershed (RCEW) in southwestern Idaho.

The LiDAR point cloud data had a maximum of four returns and mean point density of 5.6 points $\cdot \mathrm{m}^{2}$, with an average point separation of approximately $17 \mathrm{~cm}$. The mean horizontal relative and absolute accuracies were $32 \mathrm{~cm}$ and $33 \mathrm{~cm}$, respectively, as reported by the vendor. The vertical accuracy was approximately $10 \mathrm{~cm}$. Each point had the following attribute information associated: scan angle, return number, intensity, X, Y, and Z. With the methods and associated publically available LiDAR processing tools described in Streutker and Glenn (2006; http://bcal.geology.isu.edu/envitools. shtml), the point cloud data were subset to the three study areas, height-filtered to separate ground returns and vegetation returns, and converted into a raster format to generate a maximum vegetation height map of 3-m raster cell. The 3-m raster cell size was selected as the most appropriate pixel size in the study area after several different pixel sizes were examined via correlations between field- and LiDAR-based measurements of vegetation height and canopy characteristics. The raster values from the $3 \times 3 \mathrm{~m}$ pixels corresponding to field plot locations were then extracted and used for statistical analysis.

\section{Field Measurements}

Field work was completed during the months of September and October 2009. Prior to field work, a total of 150 random points were generated within the three study areas with the use of Hawth's analysis tools extension (http://www.spatialecology. com/htools) in ESRI ${ }^{\circledR}$ ArcMapTM 9.3 software (ESRI Inc., 1999-2006, http://www.esri.com). These random points were overlaid onto the 3-m-resolution LiDAR image and the corresponding pixels were selected. The coordinates of the four corners of each selected pixel were determined and a Trimble GeoXT GPS receiver (submeter postprocessing horizontal accuracy) was used to navigate to the four corners of the corresponding $3 \times 3 \mathrm{~m}$ area on the ground to establish field plots. Each $3 \times 3 \mathrm{~m}$ plot was further divided into four quadrats. Data collected in each plot included total vegetation canopy percent cover (four categorical classes: 0-24\%, 25-49\%, 50$74 \%, 75-100 \%$ ), dominant species (low sagebrush, big sagebrush, bitterbrush, herbaceous, and other), and the maximum vegetation height in each quadrat, which was measured to the nearest $5 \mathrm{~cm}$ including the reproductive stems. We assumed minimal difference in shrub vegetation heights (i.e., minimal growth in shrub canopy heights) between the timing of field work and LiDAR data acquisition, because the RCEW has not experienced major disturbance such as fire for nearly eight decades (Watts and Wambolt 1996; Wambolt et al. 2001).

\section{Statistical Analysis}

First, the relationship between the LiDAR-derived and fieldmeasured maximum shrub heights in the shrub-dominated communities was assessed using a simple linear regression to examine the strength of fit between field-based and LiDARderived shrub heights. The field-measured shrub heights were a response variable and the LiDAR-derived maximum shrub heights were a predictor variable. To evaluate the agreement between the field-measured and LiDAR-derived shrub heights further, mean squared deviation (MSD) between the two measurements was examined. The MSD is an important statistic that can be used to compare predicted and measured values, in this case LiDAR-derived and field-measured shrub heights, respectively. It can be divided into three components: standard bias (SB), nonunity slope (NU), and lack of correlation (LC) with the use of the following equations (Gauch et al. 2003):

$$
\begin{aligned}
& \mathrm{MSD}=\sum_{n} \frac{(\text { measured }- \text { predicted })^{2}}{N}, \\
& \mathrm{SB} \%=\frac{(\mu[\text { measured }]-\mu[\text { predicted }])^{2}}{\mathrm{MSD}}, \\
& \mathrm{NU} \%= \frac{(1-b)^{2} * \sum_{n} \frac{(n[\text { predicted }]-\mu[\text { predicted }])^{2}}{N}}{\text { MSD }}, \\
& \mathrm{LC} \%=\frac{\left(1-r^{2}\right) * \sum \frac{(n[\text { measured }]-\mu[\text { measured }])^{2}}{N}}{\text { MSD }},
\end{aligned}
$$

where $n$ refers to the sample size of either measured or predicted heights, $\mu$ is the mean of either measured or predicted heights, $b$ is the slope of the regression line through the plot of predicted heights as a function of measured heights, $N$ is the number of pairs of measured and predicted heights, and $r^{2}$ is the square of the correlation. SB quantifies the proportion of the MSD related to the deviance of the regression fit from a 1:1 relationship (Sankey et al. 2008a) and SB $>0$ if the intercept $a \neq 0$ (Gauch et al. 2003). NU quantifies the proportion of the 
MSD related to the deviance of the regression fit from a 1:1 relationship in the slope of the regression line (Sankey et al. 2008a) and NU $>0$ if slope $b \neq 1$. The 1:1 relationship was particularly relevant as the shrub heights measured by the active LiDAR sensor were used to predict "true" shrub heights. LC quantifies the proportion of the MSD related to the scatter of the points around the regression line (Sankey et al. 2008a). In addition, we examined the correlation between mean values ( $\pm \mathrm{SE}$ ) from the field-measured and LiDAR-derived maximum vegetation heights across all vegetation communities with the use of a simple linear regression.

Second, the LiDAR-derived maximum vegetation heights were compared among all five community types with the use of an analysis of variance (ANOVA) test with all pairwise post hoc comparisons (SPSS 15.0 for Windows, SPSS Inc., 19892006, http://www.spss.com) to determine if LiDAR-derived maximum vegetation heights significantly varied among the five community types. The LiDAR-derived vegetation heights were the response variable and the vegetation community type was the predictor variable. In addition, the field-measured maximum vegetation heights were similarly compared among the five vegetation community types with the use of an ANOVA test with all pairwise post hoc comparisons. The vegetation community type was the predictor variable, and the field-measured vegetation heights were the response variable. A total of 100 plots were used for the statistical analysis. Of these, 13 were classified as low sagebrush-dominated, 35 as big sagebrush-dominated, 22 as bitterbrush-dominated, 14 as herbaceous-dominated, and 16 as other vegetation cover types. The remaining 50 plots were excluded from the analysis. In these plots, the field notes indicated that the dominant vegetation patch size was smaller than the pixel size and individual stems or branches of taller vegetation from the neighboring pixels were hanging over the dominant vegetation. However, the heights of the overhanging stems or branches were not measured in the field. The LiDAR-derived maximum vegetation heights in some of these plots were drastically taller than the field-measured dominant vegetation heights, clearly indicating the overhanging vegetation were recorded by the laser pulse. These plots could not be used in the analysis due to the inconsistencies in the two measurements (dominant shrub height measured in the field versus maximum vegetation height in the LiDAR data).

\section{RESULTS}

The field-measured mean heights of low sagebrush-, big sagebrush-, and bitterbrush-dominated communities at the RCEW were $71 \mathrm{~cm}, 115 \mathrm{~cm}$, and $190 \mathrm{~cm}$, respectively. The standard errors associated with these heights were on average $8 \mathrm{~cm}$. The field-measured mean heights of herbaceous and other vegetation communities were $95 \mathrm{~cm}$ and $463 \mathrm{~cm}$, respectively, with standard errors of $9 \mathrm{~cm}$ and $44 \mathrm{~cm}$, respectively. The regression relationship between the fieldmeasured and LiDAR-derived maximum shrub heights in the shrub-dominated pixels were significant (adjusted $R^{2}=0.77$, $P<0.001$; Fig. 2). The intercept of the regression model was -24.52 , while the slope of the regression model was 0.94 . Further analysis of the regression fit in relation to a 1:1 line and

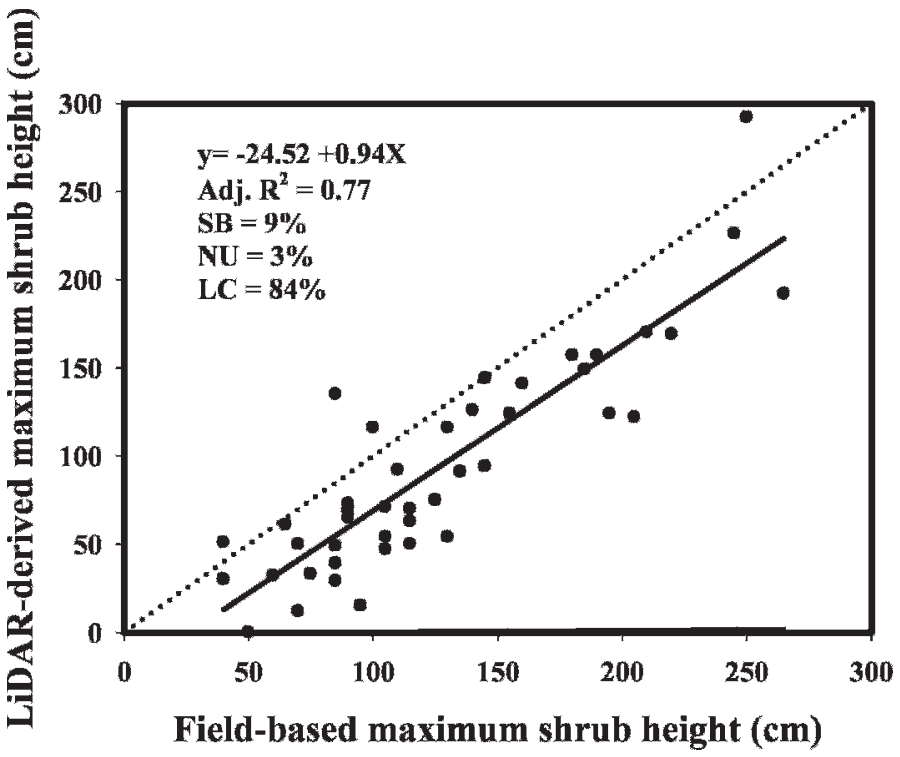

Figure 2. Correlation between LiDAR-derived and field-measured maximum shrub heights (SB indicates standard bias; NU, nonunity slope; and LC, lack of correlation).

MSD components produced SB of $9 \%$, NU of 3\%, and LC of $84 \%$ (Fig. 2). The relationship between the field-measured and LiDAR-derived means of maximum vegetation heights from all five communities was also significant (adjusted $R^{2}=0.99$, $P<0.001)$.

The ANOVA tests indicated that the field-measured maximum vegetation heights were significantly different in all pairs of comparisons (all $P$ values $<0.001$ ), except for herbaceous communities compared to low sagebrush- $(P=0.133)$ and big sagebrush- $(P=0.434)$ dominated communities (Fig. 3$)$. The LiDAR-derived maximum vegetation heights also varied significantly among the five communities $(P$ value $<0.001$; Fig. 3). All pairwise post hoc comparisons indicated that the LiDAR-derived maximum vegetation heights were significantly different in all pairs of comparisons (all $P$ values $<0.01$; Fig. 3 ) except for herbaceous-dominated communities compared to low sagebrush-dominated communities $(P=0.332$; Fig. 3$)$.

\section{DISCUSSION}

The field-measured heights of low sagebrush-, big sagebrush-, and bitterbrush-dominated communities at the RCEW were consistent with the typical heights documented in literature (Wambolt and Frisina 2002; Monsen et al. 2004; Dyer et al. 2008). The ANOVA test of the field-measured heights indicated that the average heights in the varying vegetation community types were significantly different in most comparisons and each community had a distinct height. Such distinct heights might allow LiDAR-derived vegetation height measurements to vary for each community, which can then be used to classify the communities. The resulting height-based classification might be used as structure information for firefuel-type mapping, land cover/land use mapping, environmental change monitoring, and wildlife habitat modeling. 


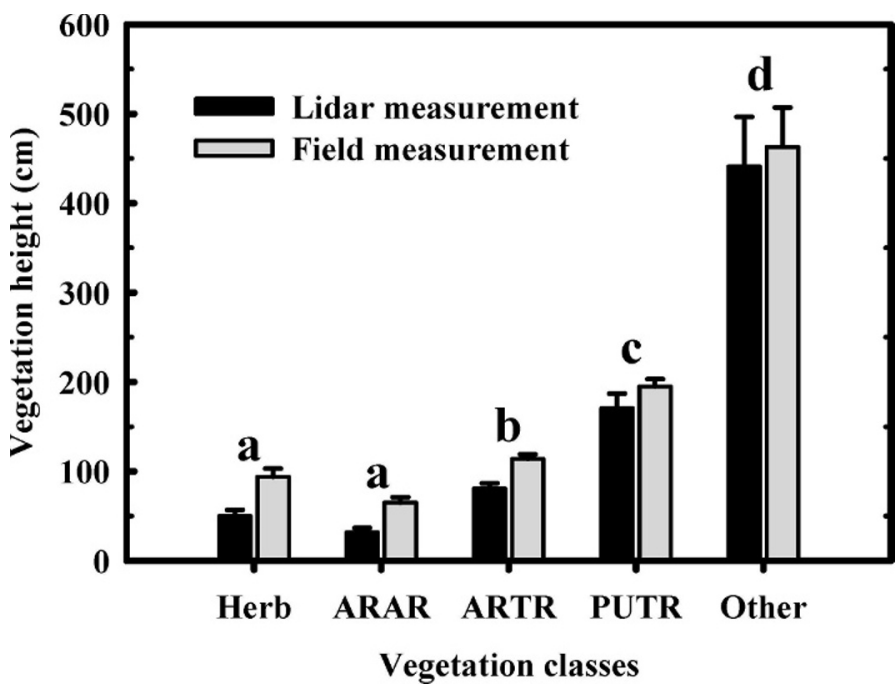

Figure 3. LiDAR-derived and field-measured mean (SE) values of maximum vegetation height in the five different vegetation communities: herbaceous (Herb), low sagebrush-dominated (ARAR), big sagebrushdominated (ARTR), bitterbrush-dominated (PUTR), and other vegetation (Other) communities. Analyses of variance of all pairwise post hoc comparisons indicated that LiDAR-derived maximum vegetation heights were significantly different in all pairs of comparisons (indicated by different letters) except for herbaceous communities compared to low sagebrush-dominated communities (indicated by the same letter [a]). Field-measured maximum vegetation heights were also significantly different in all pairs of comparisons except for herbaceous communities compared to low sagebrush- and big sagebrush-dominated communities (not indicated in the figure).

Our results demonstrated that the LiDAR-derived shrub heights were significantly and strongly correlated with the fieldmeasured heights (Fig. 2). This study was a further extension of the previous LiDAR application in sagebrush classification, which distinguished sagebrush presence and absence (Streutker and Glenn 2006). The improved ability to measure shrub heights in this study likely resulted from substantially taller vegetation at the RCEW, where average shrub height was $125 \mathrm{~cm}$. Even the shortest shrub species of low sagebrush $(71 \mathrm{~cm})$ we studied was taller than the average shrub height in the Streutker and Glenn study $(15 \mathrm{~cm})$. Furthermore, the LiDAR data set used in this study had a higher point density $\left(\sim 5.6\right.$ points $\left.\cdot \mathrm{m}^{2}\right)$ compared to the Streutker and Glenn study $\left(\sim 1.2\right.$ points $\left.\cdot \mathrm{m}^{2}\right)$. The observed coefficient of determination of 0.77 between the field-measured and LiDAR-derived shrub heights is similar to another LiDAR-based study at the RCEW, which reported a coefficient of determination of 0.80 between field-measured and LiDAR-derived juniper tree heights (Sankey et al. 2010).

Despite the strong correlation between the two measurements, the LiDAR measurements of average vegetation heights were lower than the field-measured average vegetation heights by $25-40 \mathrm{~cm}$ in the five community types. This pattern was further evidenced by the standard bias of $9 \%$, which suggested that the LiDAR-derived maximum vegetation heights were approximately $9 \%$ lower than the field-measured vegetation heights (Fig. 2). This is consistent with the results of previous LiDAR studies that documented underestimates of $4-109 \mathrm{~cm}$ in herbaceous and shrub vegetation heights of $<5 \mathrm{~m}$ (Hopkinson et al. 2004; Mitchell et al. 2009). Such underestimates of vegetation height are associated with laser pulse penetration into the vegetation canopy, insufficient laser point density to represent the canopy top, and overestimation of ground height in densely vegetated areas that prevents laser pulse penetration (Hopkinson et al. 2004). This might suggest that medium height vegetation of big sagebrush and bitterbrush-dominated communities and tall vegetation of trees can often be mapped with LiDAR data. These communities can also be mapped with less confusion among them. However, low sagebrush-dominated communities might be challenging, especially in younger communities, given the vertical error of $10 \mathrm{~cm}$ in LiDAR data. Further analysis of the mean-squared deviation in the regression model indicated that the slope of the regression was close to 1 and approximately paralleled the 1:1 line from low height vegetation to tall vegetation (Fig. 2). This result was indicated by the small nonunity value of only $3 \%$, indicating a smaller proportion of the error introduced by the regression slope compared to the intercept of the regression model. However, a large proportion of the mean-squared deviation was related to the lack of correlation, which described the scatter of the points around the regression line, though the correlation between the field-measured and LiDAR-derived shrub heights was strong.

The LiDAR-derived measurements of average vegetation heights were also significantly and strongly correlated with field-measured average vegetation heights in the five community types studied. The standard errors estimated for these average heights with the use of the LiDAR data were similar to the standard errors estimated from the field measurements. However, the standard errors estimated by LiDAR data increased as vegetation heights increased from the low-statured vegetation of herbaceous- and low sagebrush-dominated communities to tree-dominated communities. Although this pattern was similarly observed in the field measurements (Fig. 3), the increases in the standard errors estimated by LiDAR were greater than those estimated from the field measurements. This is consistent with previously documented patterns in standard errors of LiDAR measurements. Hopkinson et al. (2004) documented that the largest errors in LiDARderived height measurements were associated with the tallest vegetation observed, in their case, black spruce and aspen trees.

Our results demonstrated that the LiDAR-derived vegetation heights were significantly different among all vegetation community types studied at the RCEW, except for herbaceous-dominated vegetation community type compared to the low sagebrush-dominated community type. These results support the conclusions of previous LiDAR studies (Weltz et al. 1994; Hopkinson et al. 2004; Bork and Su 2007; Su and Bork 2007) and indicate that LiDAR-derived structure information can be used to separate low sagebrush, big sagebrush, bitterbrush, and other taller vegetation communities. In particular, LiDAR application might be successful in separating vegetation community types, which are each dominated by a species of distinct height. The co-occurrence of tall herbaceous species and low sagebrush appeared to make the distinction between herbaceous-dominated and low sagebrush-dominated community types particularly challenging. Heterogeneity of this nature caused the exclusion of many field plots from the analysis. In the excluded plots, a juniper stem or an 
overhanging branch from the adjacent pixel, that was taller than the dominant shrub vegetation, was recorded by a laser pulse. The result was an overestimation of dominant vegetation height in these pixels. Our findings suggest that the methods presented in this study might work well in rangelands with varying vegetation heights that differ substantially among community types. However, the methods need to be locally adjusted in heterogeneous vegetation community types consisting of various small patches. For future studies we recommend a smaller rasterized pixel size that is consistent with the vegetation patch size and canopy diameter of the dominant vegetation. For example, a pixel size of $1 \mathrm{~m}$ or smaller might be needed for low sagebrush height measurements, which might require a greater LiDAR point density than in this study. We expect that such cell size would reduce the inclusion of potential nondominant vegetation.

\section{MANAGEMENT IMPLICATIONS}

This study demonstrated that LiDAR data can provide significant predictions of true shrub heights. In the RCEW, the LiDAR-derived vegetation heights were also significantly different among the shrub-dominated community types. Future applications of the methods presented here might be successful in vegetation communities of distinct heights with significant differences. However, the application of these methods is limited in areas where the height differences between communities are small or in areas where vegetation patch size and canopy diameter are smaller than the rasterized pixel size. Pixel size should be carefully considered to characterize vegetation community heights accurately.

\section{REFERENCES}

Anderson, J. E., And R. S. Inouye. 2001. Landscape-scale changes in plant species abundance and biodiversity of a sagebrush steppe over 45 years. Ecological Monographs 71:531-556.

BAKER, W. L. 2006. Fire and restoration of sagebrush ecosystems. Wildlife Society Bulletin 34:176-185.

Blaisdell, J. P., R. B. Murray, and E. D. McArthur. 1982. Managing intermountain rangelands-sagebrush-grass ranges. Ogden, UT, USA: US Department of Agriculture, Forest Service, Intermountain Forest and Range Experiment Station, General Technical Report INT-134. 41 p.

BoRK, E. W., AND J. G. Su. 2007. Integrating LiDAR data and multispectral imagery for enhanced classification of rangeland vegetation: a meta analysis. Remote Sensing of Environment 111:11-24.

Dyer, D., R. O'Beck, and G. L. Noller. 2008. Plant guide: antelope bitterbrush Purshia tridentate (Pursh) DC. US Department of Agriculture-Natural Resources Conservation Service Plants Database. Available at: http://plants. usda.gov. Accessed 14 December 2009.

Gauch, H. G., Jr., J. T. G. Hwang, and G. W. Fick. 2003. Model evaluation by comparison of model-based predictions and measured values. Agronomy Journal 95:1442-1446.

Hopkinson, C., L. E. Chasmer, G. Zsigovics, I. F. Creed, M. Sitar, P. Treitz, and R. V. Maher. 2004. Errors in LiDAR ground elevation and wetland vegetation height estimates. Proceedings of the ISPRS working group VIII/2, "LaserScanners for Forest and Landscape Assessment"; 3-6 October 2004; Freiburg, Germany. ISPRS 36, Part 8/W2.

Hunt, E. R., JR., J. H. Everitt, J. C. Ritchie, M. S. Moran, D. T. Booth, G. L. Anderson, P. E. Clark, and M. S. Seyfri. 2003. Applications and research using remote sensing for rangeland management. Photogrammetric Engineering and Remote Sensing 69:675-693.

JaKubausKas, M., K. KindSCher, And D. DeBInSKI. 2001. Spectral and biophysical relantionships of montane sagebrush communities in multi-temporal SPOT XS data. International Journal of Remote Sensing 22:1767-1778.

Knick, S. T., J. T. RotenberRy, And T. J. ZarRiello. 1997. Supervised classification of Landsat Thematic Mapper imagery in a semi-arid rangeland by nonparametric discriminant analysis. Photogrammetric Engineering \& Remote Sensing 63:79-86.

Kokaly, R. F., D. G. Despain, R. N. Clark, and K. E. Livo. 2003. Mapping vegetation in Yellowstone National Park using spectral feature analysis of AVIRIS data. Remote Sensing of Environment 84:437-456.

Kremer, R. G., and S. W. Running. 1993. Community type differentiation using NOAA/AVHRR data within a sagebrush-steppe ecosystem. Remote Sensing of Environment 46:311-318.

Mitchell, J. J., N. F. Glenn, T. Sankey, and D. Derryberry. 2009. LidAR canopy height and shape measurements in a sagebrush steppe ecosystem. Eos Transactions, American Geophysical Union 90(52, Fall Meeting Suppl):Abstract B31A-0320.

Monsen, B., R. Stevens, and N. L. Shaw. 2004. Restoring western ranges and wildlands. Fort Collins, CO, USA: US Department of Agriculture, Forest Service, Rocky Mountain Research Service, General Technical Report 136, Vol. 2. p. 295-698+index.

Mundt, J. T., D. R. Streutker, and N. F. Glenn. 2006. Mapping sagebrush distribution using fusion of hyperspectral and LiDAR classifications. Photogrammetric Engineering and Remote Sensing 72:47-54.

NoRD, E. C. 1965. Autecology of bitterbrush in California. Ecological Monograph 35:307-334.

Okin, G. S., D. A. Roberts, B. Murray, and W. Okin. 2001. Practical limits on hyperspectral vegetation discrimination in arid and semiarid environments. Remote Sensing of Environments 77:212-225.

Ramsey, R. D., D. L. Dennis, and C. McGinty. 2004. Evaluating the use of Landsat $30 \mathrm{~m}$ Enhanced Thematic Mapper to monitor vegetation cover in shrub-steppe environments. Geocarto International 19:39-47.

Rango, A., M. J. Chopping, J. C. Ritchie, K. Havstad, W. Kustas, and T. Schmugge. 2000. Morphological characteristics of shrub coppice dunes in desert grasslands of southern New Mexico derived from scanning LiDAR. Remote Sensing of Environment 76:26-44.

Riano, D., E. Chuvieco, S. L. Ustin, J. Salas, J. R. Rodriguez-Perez, L. M. Ribeiro, D. X. Viegas, J. M. Moreno, and H. Fernandez. 2007. Estimation of shrub height for fuel-type mapping combining airborne LiDAR and simultaneous color infrared ortho imaging. International Journal of Wildland Fire 16: 341-348.

Ritchie, J. C., K. S. Humes, And M. A. Weltz. 1995. Laser altimeter measurements at Walnut Gulch watershed, Arizona. Journal of Soil and Water Conservation 50:440-442.

Sankey, J. B., D. J. Brown, M. L. Bernard, and R. Lawrence. 2008a. Comparing local vs. global visible and near-infrared (VisNIR) diffuse reflectance spectroscopy (DRS) calibrations for the prediction of soil clay, organic $\mathrm{C}$ and inorganic $\mathrm{C}$. Geoderma 148:149-158.

Sankey, T. T., N. Glenn, S. Ehinger, A. Boehm, and S. Hardegree. 2010. Characterizing western juniper (Juniperus occidentalis) expansion via a fusion of Landsat TM5 and LiDAR data. Rangeland Ecology \& Management 63:514-523.

Sankey, T. T., C. Moffet, and K. Weber. 2008b. Postfire recovery of sagebrush communities: assessment using SPOT-5 and very large-scale aerial imagery. Rangeland Ecology \& Management 61:598-604.

Seyfried, M., R. Harris, D. Marks, and B. Jacob. 2001. Geographic database, Reynolds Creek Experimental Watershed, Idaho, United States. Water Resources Research 37:2825-2829.

Sivanpillal, R., AND D. T. Bо0тH. 2008. Characterizing rangeland vegetation using Landsat and 1-mm VLSA data in central Wyoming (USA). Agroforestry Systems 73:55-64.

Sivanpillai, R., S. D. Prager, and T. O. Storey. 2009. Estimating sagebrush cover in semi-arid environments using Landsat Thematic Mapper data. International Journal of Applied Earth Observation and Geoinformation 11:103-107. 
Slaughter, C. W., D. Marks, G. N. Flerchinger, S. S. Van Vactor, and M. Burgess. 2001. Thirty-five years of research data collection at the Reynolds Creek Experimental Watershed, Idaho, United States. Water Resources Research 37:2819-2823.

StreutKer, D. R., And N. F. Glenn. 2006. LiDAR measurement of sagebrush steppe vegetation heights. Remote Sensing of Environment 102:135-145.

Su, J. G., AND E. W. BoRK. 2007. Characterization of diverse plant communities in Aspen Parkland rangeland using LiDAR data. Applied Vegetation Science 10:407-416

Suring, L. H., M. M. Rowland, and M. J. Wisdom. 2005. Identifying species of conservation concern. In: M. J. Wisdom, M. M. Rowland, and L. H. Suring [EDS.]. Habitat threats in the sagebrush ecosystem: methods of regional assessment and applications in the Great Basin. Lawrence, KS, USA: Alliance Communications Group. p. 150-162.

Tilley, D. J., D. Ogle, L. St. John, and B. Benson. 2006. Plant guide: big sagebrush Artemisia tridentata Nuttall. US Department of Agriculture Natural Resources Conservation Service, Plants Database. Available at: http://plants.usda.gov. Accessed 14 December 2009.
Tueller, P. T. 1989. Remote sensing technology for rangeland management. Journal of Range Management 42:442-453.

Wambolt, C. L., And M. R. Frisina. 2002. Montana sagebrush guide. Bozeman, MT, USA: Montana Department of Fish, Wildlife and Parks. $82 \mathrm{p}$.

Wambolt, C. L., K. S. Walhof, and M. R. Frisina. 2001. Recovery of big sagebrush communities after burning in south-western Montana. Journal of Environmental Management 61:243-252.

Washington-Allen, R. A., N. E. West, R. D. Ramsey, and R. A. Efroymson. 2006. A protocol for retrospective remote sensing-based ecological monitoring of rangelands. Rangeland Ecology \& Management 59:19-29.

WatTs, M. J., AND C. L. WamboLt. 1996. Long-term recovery of Wyoming big sagebrush after four treatments. Journal of Environmental Management 46:95-102.

WeBer, K. T. 2006. Challenges of integrating geospatial technologies into rangeland research and management. Rangeland Ecology \& Management 59:38-43.

Weltz, M. A., J. C. Ritchie, and H. D. Fox. 1994. Comparison of laser and field measurements of vegetation heights and canopy cover. Water Resources Research 30:1311-1320. 